Open Access

\title{
Erratum to: Analysis and reduction of eddy current effects induced by tesseral end zonal gradient coils in different collimator geometries for SPECT/MRI integration
}

Amine M. Samoudi ${ }^{1 *}$, Karen Van Audenhaege ${ }^{2}$, Gunter Vermeeren ${ }^{1}$, Emmeric Tanghe ${ }^{1}$, Luc Martens ${ }^{1}$, Roel Van Holen ${ }^{2}$ and Wout Joseph ${ }^{1}$

Any correspondence should be addressed to George Loudos, Supplement 'Proceedings of the 4th PSMR Conference on PET/MR and SPECT/MR' organizer: gloudos@teiath.gr

\section{Erratum}

Unfortunately, the original version of this article [1] contained an error. The author's name, 'Amine M Samoudi', was spelt incorrectly. This can be found corrected in the author list above.

\section{Author details}

${ }^{1}$ INTEC, Ghent University/iMinds, Ghent, Belgium. ${ }^{2}$ ELIS, Ghent University/iMinds, Ghent, Belgium.

Published online: 09 November 2015

\section{Reference}

1. Samudi AM, Karen Van A, Gunter V, Emmeric T, Luc M, Roel Van H, et al. Analysis and reduction of eddy current effects induced by tesseral end zonal gradient coils in different collimator geometries for SPECT/MRI integration. EJNMMI Physics. 2015;2(1):A51.

\section{至 Springer}

(ㄷ) 2015 Samoudi et al. Open Access This article is distributed under the terms of the Creative Commons Attribution 4.0 International License (http://creativecommons.org/licenses/by/4.0/) which permits unrestricted use, distribution, and reproduction in any medium, provided you give appropriate credit to the original author(s) and the source, provide a link to the Creative Commons license, and indicate if changes were made.
Submit your manuscript to a SpringerOpen ${ }^{\circ}$ journal and benefit from:

- Convenient online submission

- Rigorous peer review

- Immediate publication on acceptance

- Open access: articles freely available online

- High visibility within the field

- Retaining the copyright to your article

Submit your next manuscript at springeropen.com 